\title{
Terminological Lexicography as a Novelty of Modern Linguistics (Its Place in Modern Czech Linguistics)
}

Yevheniya Ishchuk

(Brno, Czech Republic)

For today, in the period of scientific and technical progress we can all more often meet with researches and projects of scientists that at work, mainly, are concentrated on the acquaintance of society with the origin and presentation of new scientific disciplines. In this article, the basic range of problems of the newest linguistic discipline of terminography is presented in details, and principles of its aspiration and actuality are described. The term "terminography", coined on the analogy of lexicology/lexicography and terminology/terminography, is tending to replace the older term "terminological lexicography".

First of all, we need to describe what it is. According to the Lexicographic Dictionary, terminography is a complex of activities dealing with the design, compilation, use and evaluation of terminological dictionaries ${ }^{1}$. The Ukrainian researcher O. Ivanova also inclines to believe that terminological lexicography is a complex science that deals with the theory and practice of compiling terminological dictionaries, combining terminology as a science of terms, and lexicography as the art of creating dictionaries ${ }^{2}$. That is, according to the above definitions, we can say that the object of this scientific discipline is a branch/terminological dictionary, and the subject-the creation of a methodology for compiling different types of terminological dictionaries.

The Czech researcher Josef Schwarz, in turn, considers terminological lexicography to be broader and states that terminography is an area of terminology that takes into account the terms and concepts and the creators of terminological products

1 HARTMANN, R. R. K., JAMES, G.: Dictionary of Lexicography. London and New York: Routledge, 1998, s. 139.

2 İVANOVA, O.: Zmist i struktura ponjattja «terminolohična leksykohrafija». In: Ukrajins'ka termìnolohìja ì sučasnìst': zbìrnyk naukovych prac'. Kyjiv: KNEU, 2007. Vypusk 7, s. 331-333. 
(dictionaries, databases, standards, etc. $)^{3}$. In this context, instead of individual names of terminography production, the clearer term of terminological work is also used.

The science of terminological products came into its existence at the end of the 2oth century and we now consider it a new and very popular unexplored science that helps us with our present. The definition of terminography as a separate discipline is one of the main theoretical problems in the linguistic field, because there are still debates about the original origin of the linguistic discipline-either there is still a single part of lexicography, or its discipline emerges as a complex part of terminology. In our opinion, the terminography can be considered as separate, because the discipline focuses not only on a particular field of human knowledge, but also on the basic approach to the processing of lexical units (in this case, terms). As is well known, lexicography is characterized by a semasiological approach (progression from form to meaning), in contrast to terminography, where it converts the opposite, onomasiological approach from meaning to form, i.e. to a specific meaning/term, the terms are marked as to indicate the meaning. As a result, we can see that terminological lexicography is a complex science dealing with the theory and practice of compiling terminology dictionaries, combining terminology as a science of concepts, and lexicography as a science of creating dictionaries.

Otherwise, the connection between terminography and other linguistic disciplines is obvious. For example, the relationship between terminology and terminography is similar to the relationship between their genetic concepts, i.e. lexicology and lexicography. Lexicology examines the lexical units of a certain language in terms of its meaning and use, lexicography deals with the theoretical, methodological and practical aspects of creating dictionaries. Terminological lexicography is closely related to a number of other linguistic disciplines, sociology, psychology, computer science, computer technology and others.

This linguistic discipline, like other sciences, has its specific theory and methodology. First of all, it should be noted that there are theoretical and practical parts in terminological lexicography. Theoretical terminography considers the history and theory of terminography to be practical; mainly compiling and publishing dictionaries in various fields of knowledge and creating other terminography products. The main problems of the theory of terminography include the issues related to the compilation of terminological dictionaries, databases, standards, while the history of terminography is a kind of generalization of all lexicographic material from the first publications to the next editions. The theoretical part is considered as any basis for the practical, i.e. is a certain basis of accumulated knowledge for their implementation in practice. It

3 SCHWARZ, J.: Vybrané teoretické a metodologické problémy terminografie: poznatky z tvorby české terminologické databáze knihovnictví a informační vědy. Národní knihovna, 14, 2003, č. 1, s. 21. 
is the practical necessity to compile terminological products and develop theoretical provisions on which specific methods of terminological research can be built up.

At full examination of the terminography can be said that the main areas of work of this discipline include the creation of a reliable classification and typology of special dictionaries, list of terminography parameters, analysis of the impact of the methodological establishment on the dictionary and its individual quality parameters and features of its implementation, study of terminology vocabulary properties, study the methods of selection and organization of terminological information in the dictionary, as well as the methods of technical presentation of lexicographic and terminological data, etc.

As mentioned above, the subject of the study of terminography is a specific terminological work, in which an important place $s$ taken by terminological dictionaries, which today are mostly created as outputs from terminological databases. We may encounter different names of this type of dictionaries in different sources. In general, a terminological dictionary is a kind of a linguistic dictionary, a set of terminological terms in which the terminology of the field (or several branches) of knowledge is given. The creation of terminological dictionaries or, as they are also called, dictionaries of special vocabulary, is based on the relevant requirements of their compilation and occupies a prominent place in the list of other terminological products. They are a kind of tool in almost all types of terminological activities. Therefore, the role of such types of dictionaries is growing significantly in all areas of knowledge and their number is increasing accordingly.

Each sector of a specific area of terminology is based on more detailed terminology, temporarily assigned to another and narrower specialization. In the Czech Republic, for example, we can find the following types of dictionaries:

\section{Linguistic and language dictionaries}

1. Svatopluk Pastyř́k. Základní jazykovědné a stylistické pojmy: výběrový slovník lingvistické terminologie. Hradec Králové, 2010;

2. Jaroslav Kobr. Lingvistika: slovník jazykovědných termínů. Praha, 2012;

3. Josef Línek. Česko-anglický a anglicko-český slovník jazykovědných pojmů studijní opora. Olomouc, 2012.

\section{Technical dictionaries}

1. Anglicko-český, česko-anglický technický slovník. Praha, 1992;

2. Jiří Hynek. Praktický technický slovník: anglicko-český, česko-anglický. Fraus, 2007;

3. Antonín Radvanovský. Italsko-český technický slovník. Academia, 2008. 


\section{Medical dictionaries}

1. Stanislav Trojan a Miloš Langmeier. Slovníček lékařské fyziologie. Galén, 2006;

2. Josef Dvořák. Logopedický slovník: terminologický a výkladový. Ždár nad Sázavou: Logopedické centrum, 2007;

3. Josef Sedláček. Anglicko-český stomatologický slovník. Grada, 2007;

4. Martin Vokurka a Jan Hugo. Praktický slovník medicíny. Maxdorf, 2008;

5. Jaroslav Doubek, Jaroslava Tomenendálová a Astron studio. Terminologický slovník laboratorní diagnostiky. Brno, 2014.

\section{Legal terminology dictionaries}

1. Josef Fiala. Malá právnická encyklopedie. Praha, 1994;

2. Jiří Brynda. Španělsko-český právnický a ekonomický slovník. Linde, 2007;

3. Radovan Ryska. Slovník základních pojmů z práva. Fortuna Libri, 2008;

4. Markéta Larišová. Francouzsko-český, česko-francouzský právnický slovník. Aleš Čeněk, 2008;

5. Dušan Hendrych a kolektiv. Právnický slovník. C. H. Beck, 2009.

\section{Economic dictionaries}

1. Helena Fialová a Jan Fiala. Malý ekonomický slovník s výkladem pojmů v češtině $a v$ angličtině. A plus, 2006;

2. Martina Imider, Mojmír Vavrečka a Václav Lednický. Česko-německý, německo-český slovník managementu. Computer Press, 2007;

3. Josef Bürger, sr. A Radek Blaheta. Praktický ekonomický slovník: anglicko-český, česko-anglický. Fraus, 2007.

\section{Scientific dictionaries}

1. Walter Brugger. Filosofický slovník. Naše vojsko, 1994;

2. Lutz Müller a Anette Müller. Slovník analytické psychologie. Portál, 2006;

3. Miroslav Ressler. Informační věda a knihovnictví: výkladový slovník české terminologie z oblasti informační vědy a knihovnictví. Vysoká škola chemicko-technologická (VŠCHT), 2006;

4. Jan Jandourek. Sociologický slovník. Portál, 2007;

5. Jan Průcha, Eliška Walterová a Jiří Mareš. Pedagogický slovník. Portál, 2013;

6. Ireneusz Krech, Pavel Tlustý a Markéta Vošmiková. Česko-polský, polsko-český matematický slovník. České Budějovice, 2009;

7. Rastislav Tóth. Politologický slovník. Portál, 2015. 


\section{Professional and craft dictionaries}

1. Richard Barvínek a Alois Kouba. Slovník pojmů ve výstavbě: geotechnika a zakládání. Praha: Informační centrum ČKAIT, 2006;

2. Marie Dohnalová a Jaroslav Malina. Slovník antropologie občanské společnosti. CERM, 2006;

3. František Mareček, Eva Pekárková a Jindra Janovská. Anglicko-český slovník pro zemědělce. Praha, 2006;

4. Jiří Vedral. Česko-anglický slovník pekařský. Praha, 2002;

5. Slovník psychiatrických termínů. Psychiatrické centrum, 1998.

\section{Financial, accounting and business terminology dictionaries}

1. L’ubomír Grúň a Michal Černý. Malý slovník finanční, bankovní a obchodní. Olomouc, 2006;

2. Vladimír Munzar a Jarmila Čuhlová. Slovník základních pojmů z účetnictví. Fortuna, 2010;

3. Magda Stehnová. Odborný slovník pro účetnictví, výkazy a DPH: česko-německý a německo-český. KDP ČR, 2006.

\section{Dictionaries with a religious topic}

1. Jan Heller. Biblický slovník sedmi jazyků: hebrejsko-řecko-latinsko-anglicko-německo-mad’arsko-český. Praha, 2001;

2. Jan Royt. Slovník biblické ikonografie. Karolinum, 2006;

3. Rupert Berger. Liturgický slovník. Vyšehrad, 2008.

\section{Dictionaries of vehicles or traffic}

1. Jan Zdeněk a Bronislav Ždánský. Výkladový automobilový slovník. Computer Press, 2011;

2. Ivan Řáda. Česko-anglický letecký slovník. Leda, 2005;

3. Terminologický slovník dopravní telematiky. Sdružení pro dopravní telematiku České republiky, 2006;

4. Ivo Machačka a Filip Machačka. Anglicko-český slovník: automobily, silniční vozidla: výroba, provoz, servis, opravárenství. Systemconsult, 2009.

\section{Sports terminology dictionaries}

1. Jiří Langer. Slovník pojmů znakového jazyka pro oblast tělesné výchovy a sportu. Praha: Fortuna, 2006; 
2. Josef Dovalil a kol. Lexikon sportovního tréninku. Karolinum, 2008;

3. Eva Pokorná a Róbert Kandráč. Anglicko-český, německo-český, česko-německo-anglický slovník sportovního tréninku. Grada, 2011;

4. Milena Machalová, Eva Vysloužilová a kol. Česko-ruský slovník sportovní terminologie. Univerzita Palackého v Olomouci, 2014.

\section{Government terminology dictionaries}

1. Oldřich Berka a Věra Lánská. Slovník česko-francouzský a francouzsko-český z oblasti vzdèlávání, zaměstnávání a veřejné správy. Optys, 2007;

2. Petr Kratochvil. Slovník teorie mezinárodních vztahů. Oeconomica, 2007;

3. Jiří Kroupa. Slovník soudobé politiky a mezinárodních vztahư. Wolters Kluwer, 2015;

4. Jan Malinovský a Jan Sucháček. Velký anglicko-český slovník vysvětlující pojmy regionálního rozvoje a regionální politiky Evropské unie. Ostrava: VŠB - Technická univerzita Ostrava, 2006.

\section{Dictionaries of special vocabulary}

1. Rudolf Horák a Jan Kyselák. Terminologický slovník vybraných pojmů z oblasti evakuace. Brno: Univerzita obrany, 2006;

2. David Ullrich. Terminologický slovník vybraných pojmů z oblasti záchrany osob. Brno: Univerzita obrany, 2011;

3. Ivana Knaislová a Jan Knaisl. Encyklopedie jógy. Rubico, 2015;

4. Boris Beinhauer. Německo-český filatelistický příruční slovník. Opava, 2006.

This classification of dictionaries is quite common and it was created only for better understanding of the presented published terminological dictionaries. With regard to publishers and publishing centres dealing directly with the printing of dictionaries and encyclopaedic publications, it should be mentioned that the most productive ones in the Czech Republic are in large cities, for example in Prague, Brno, Olomouc and Pardubice. In some cases, editions of press dictionaries are closely connected with universities and the relevant institutions. Many of the published special dictionaries and encyclopaedias are considered to be foreign/imported literature, despite the fact that the material of these editions was collected and published on the territory of the Czech Republic; the publications in English, German, and French are very popular. This is definitely a great advantage for foreign students and teachers and for the people who want to get acquainted with the literature in the original language.

With regard to other products of practical terminography activity, the following distinction can be made between them:

1. terminological records (entries containing terminological data relating to one term); 
2. terminological databases/terminological memory (they contain terminological data with a fixed record structure for information, standardization and harmonization purposes);

3. terminological databanks (more general term, electronic data are stored in the basic form); 4. terminological standards (deal with terms together with their definitions, sometimes with explanations and examples).

If we are talking about the creation of an individual terminography product, it is necessary to determine the basic concepts of future terminological work first. These include creating a terminography team, determining the starting points of the future project and terminography procedures, determining the purpose, advantages, main goals, timeliness and intent of the user, form, structure, theoretical foundations, product implementation methods, defining the thematic area, identifying terms and concepts, processing of terminological information, etc.

Modern lexicographer, as a leading specialist, not only compiles vocabulary or other terminological products, combines not only work on materials with traditional academic activities, but also actively participates in the development of theoretical foundations of his science, art, craft and more. Creating a separate terminography team plays an important role in the production of a truly high-quality terminography product. The professional level of individual employees and their professional skills in solving theoretical, methodological and practical terminography issues, maintaining certain formal levels of work, adherence to the basic principles of work are the determining factors for the quality of the final terminological product. Among such experts it is necessary to separate terminographers who are usually experts in the field, which is the terminological database is created for, who carry out their own collection and creation of terminological information; linguists who process a sufficient professional 1 level of expertise; methodologies who determine the basic conceptual basis, the scope of the processed terminological information and specific methods of work; technicians who create and operate software for the creating terminological databases; other external staff from various fields of activities who mostly process terminological records; a project coordinator, who controls the activities of the whole team and ensures a professional communication, etc.

Each individual language is known to have its own terminological fund; each branch has its own rich terminology, the number of which at the present stage is increasingly supplemented by new lexical units, so the scientific terminology of any language requires further systematization and guidance. Based on this, the need to create new terminological products is growing every day, which is one of the main tasks of modern terminology.

New terminological norms are published daily, new terminological conferences are held and new terminological institutes and committees are created. The issue 
of terminography was relevant at the end of the last century, the study of terminography remains very relevant today, because the research on the purposes of terminography production includes mapping professional terminology, capturing its latest developments, standardizing the meaning and forming terms and concepts, harmonizing terminology at the national and international levels, rapid development of terminology, organization and systematization of new terms and expressions, publishing a high quality dictionary of Slovak production or presentation its on-line version, the human factor and sociological aspect, etc.

With each passing day, new areas of knowledge emerge, so the range of terminological products in general and dictionaries in particular expands significantly. These include various information systems, document management systems, regulatory regulation of production, etc., resulting in new types of terminological dictionaries and databases. This is a practical need to compile dictionaries of special vocabulary and requires the development of a certain theoretical basis. Specific research methods related to the development of relevant industry terminology can be based on its main provisions.

Terminological lexicographical works are intended for a wide range of scientists, teachers, students of all specialties or a particular specialty, graduate students, pupils, scientists and technicians and others. The creation of terminological products should be based on assessment of the effectiveness of their further use. However, attention must be paid to the fact that not each terminological work will be able to remain balanced for a long time, because there will be a need to supplement or improve it every day. The enrichment of any kind of language with new terms has today become a large-scale and continuous process.

The beginning of the 21st century is not only a synthesis of knowledge from previous studies, supplement, editions and improvements of the previous performances, but also a new vision in the development of this or that science. Reviewing the individual aspects of scientific history in general and some of its industries in particular, first of all, we should turn our attention to the beginning of the terminological science. Each study, each new publication or a new dictionary will fill its life and help evolve year by year. Of course, on this way there were some unsuccessful attempts and banned publications and critical attitudes, but at the same time, we should not forget the "golden years" of publishing, when terminological dictionaries were on top of publication activities. Summarizing the legacy of the past, we can accurately claim that the 21th century is a symbolic transition to a new, more modern publication future, opening a new publication era, time of scientific and technical progress and new discoveries. 


\title{
References:
}

İVANOVA, O.: Zmist ì struktura ponjattja «terminolohična leksykohrafija». In: Ukrajins'ka termìnolohìja ì sučasnìst': zbìrnyk naukovych prac'. Kyjiv: KNEU, 2007. Vypusk 7, s. 331-333.

HARTMANN, R. R. K., JAMES, G.: Dictionary of Lexicography. London and New York: Routledge, 1998, s. 139.

SCHWARZ, J.: Vybrané teoretické a metodologické problémy terminografie: poznatky $z$ tvorby české terminologické databáze knihovnictví a informační vědy. Národní knihovna, 14, 2003, č. 1, s. 21.

\author{
About the author \\ Yevheniya Ishchuk \\ Masaryk University, Faculty of Arts, Department of Slavonic Studies, Brno, \\ Czech Republic \\ yevheniya_ishchuk@ukr.net
}


